\title{
Local Tendencies in Urban Design Viewed Through the Case Study of Contemporary Development Design in Context of Traditional Architecture
}

\author{
Mirko Grbić, Dušan Tomanović, University of Priština in Kosovska Mitrovica \\ Peter Gabrijelčič, University of Ljubljana
}

\begin{abstract}
Villages with significant artistic and cultural value have been developed throughout centuries of turbulent past of Montenegrin coastal and hinterland area. Today, these settlements represent a valuable source of information and are a common subject of research and inspiration to many architects. Through the example of recently designed development, this research aims to show the methods and advantages of contemporary design in traditional context. The review of the traditional architecture and urban design gives insight into qualitative and functional characteristics of building styles that witness centuries of experience and are therefore considered as sustainable. Methodological reference to the traditional building construction considers all the influencing factors that determine the qualitative and functional advantages of local ways of construction. The aim of the research is to implement the research process and to initiate the revival of traditional settlements in order to regain the significance they used to have, in contrast to the presently failed urban attempts. There is a tendency to give preference of designing in context of traditional architecture, considering the advantage of such constructions.
\end{abstract}

Keywords - Montenegrin coast and hinterland, traditional architecture, old-new context.

\section{INTRODUCTION}

During the tumultuous past of the Montenegrin coast and its hinterland, villages of great historical, artistic and cultural value have been created, presenting an abundant source of material. They are still a subject of the research for many architects and professional institutions [2].

Their spatial organization is caused by the configuration of the terrain, geological, climatic conditions and historically defensive factors. Due to contemporary social movements and the migration of inhabitants, these settlements have been increasingly neglected and depopulated [3].

New settlements have developed along the coastal line, which are completely different from the old ones, causing to devastate them both quantitatively and qualitatively.

The ultimate goal of urban planners is to encourage the revival and regain the importance the villages used to have, because today's urban planning has failed to create anything better than what has been created throughout the centuries.

Through the example of successful modern shaped settlements, e.g. the Ivanovic village in Becici, built in the traditional way demonstrates the method and advantage in the context of the traditional design. Through the review of the old traditional architecture, qualitative and functional advantages of building were considered, that witness centuries of experience, respecting all the influential factors for their sustainability.

\section{Methodology}

The following methods were applied: data collection on the site and in literature (domestic and foreign). Collecting data on site refers to architectural observations, photographing and collecting oral information on site (interviews, surveys, etc.). As a result of authors' profound research on site, the selection of topics was made. Both literature review and observations on site determined the case study.

\section{Determining Factors of Traditional Architecture}

\section{A. Terrain}

The region is mostly mountainous and the land is divided into two parts: the mountain and coastal part. The coastal part is a narrow strip between the sea and the mountain ridge on a steep slope towards the sea, while the mountain part is larger and is 600-800 $\mathrm{m}$ above sea level. This area of Montenegrin coast (Fig. 1) between the towns of Bar and Budva is called Pastrovici area. The region around Tivat, with slopes of Vrmac and Lustica peninsula, has a variety of geologic, soil, climate and vegetation characteristics that influenced the evolution of the types of settlements in this territory. The coastal part of the bay of Kotor is a narrow slope.

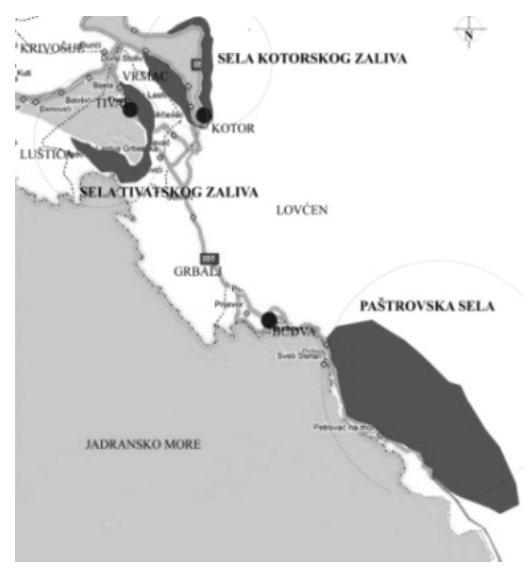

Fig. 1. Map of the Montenegrin coast [9]. 


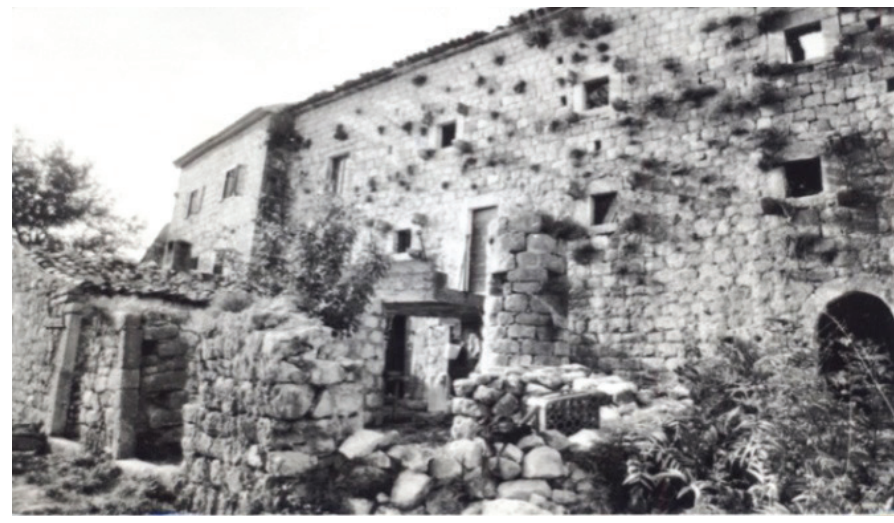

Fig. 2. Dabkovići, Paštrovići [M. Grbić].

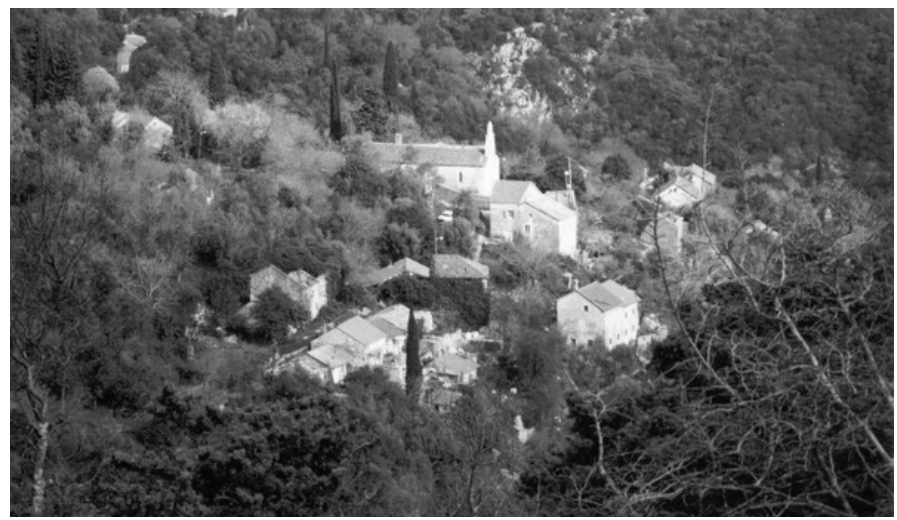

Fig. 4. Gornja Lastva,the bay of Tivat [M. Grbić].

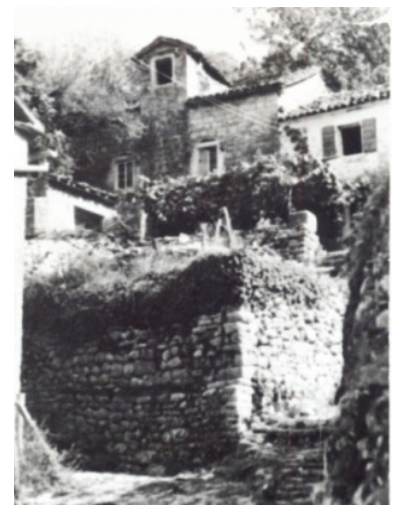

Fig. 3. Gornji Stoliv, the bay of Kotor [M. Grbić].

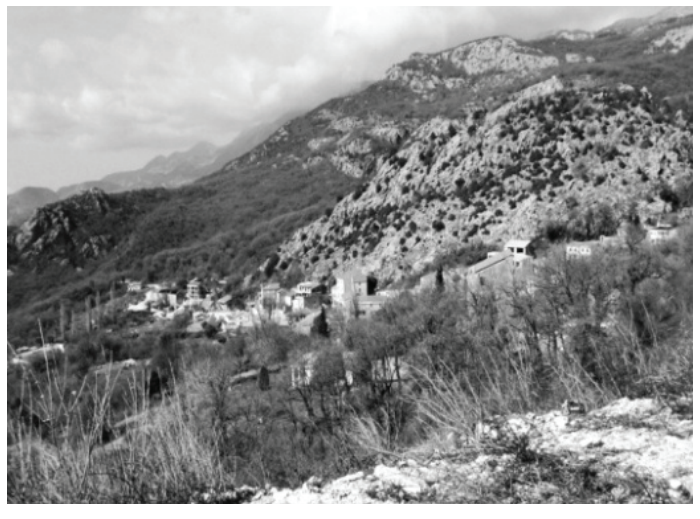

Fig. 5. Kuljače, Paštrovići [M. Grbić].

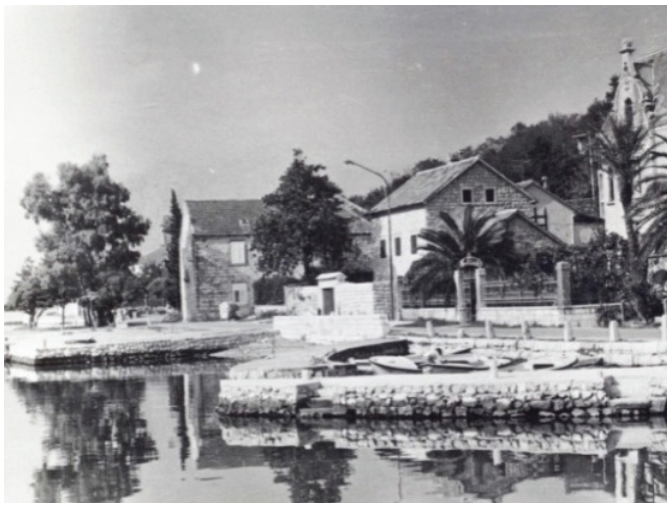

Fig. 6. Dobrota, the bay of Kotor [M.Grbić].
As a consequence of the configuration of terrain, settlements were formed mainly on the steep slopes above the fields and in the Bay area along the coast [1].

\section{B. Climate}

Climate is different because of the uneven height of the terrain. It is Mediterranean climate and summers are generally warm and dry. The prevailing winds are the cooling summer maestral (north-western), jugo (south-eastern) and bura (north-eastern). Bura is the most dangerous; it blows down from the mountains and can grow in strength very quickly.

\section{Historical Influences}

Due to its geographical location and natural life conditions, this area was inhabited by people of different cultures and exposed to many political and cultural influences. Until World War I, the evident historical influences were: Illyrian, Roman and Byzantine, Venetian, Austrian, Russian, French era. Each of these eras has influenced economy and culture of this area [1].

\section{Spatial Organization of Rural Settlements}

The spatial organisation of rural settlements was influenced by the factors mentioned in Section II. The choice of building methods and building materials could not and did not have to go any further than those available: local stone, wood, stone slabs, hogs-back tiled roof. All these influences were applied to their total effect.

Depending on the location, the villages were organized as follows:

\section{A. Villages of Compact Type}

The houses were built close together in a row of 7-8 units. The villages of this type are characterized by organic compactness the core that is spread into various directions - the cluster structure, with longitudinal and transversal positioning in relation to the slope of terrain. Created as a result of natural landforms and soil characteristics, they are located on the narrow, less fertile ground. The villages of Pastrovici area (Fig. 2) were built in rows, while similar rows were created in the villages of Kotor, by coupling the villages of the scattered type (Fig. 3). Unlike them, the compact villages of the bay of Tivat are characterized by organic compact core that is spread all over the bay, sometimes forming rows [3].

\section{B. Villages of Dispersed Type}

This type usually consisted of two or more hamlets, usually distanced 200-300 meters away from each other, but in some cas- 
TABLE I

Types of Groupings of Houses (Authors of the Article)

\begin{tabular}{|c|c|c|c|}
\hline 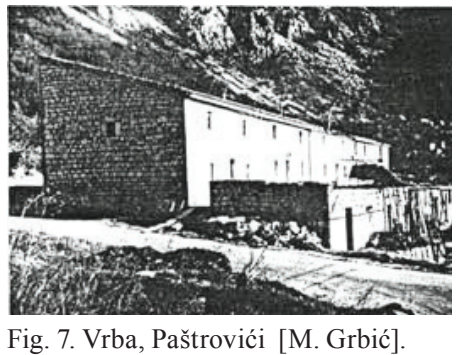 & $\begin{array}{l}\text { - A row under a single slope roof } \\
\text { house with the same cross section of } \\
\text { the house. }\end{array}$ & $\begin{array}{l}\text { nques } \\
\text { Fig. 11. Pržno, Paštrovići [ M. Grbić ]. }\end{array}$ & $\begin{array}{l}\text { - A row under numerous dou- } \\
\text { ble slope roofs set transversely with } \\
\text { respect to a number of different } \\
\text { cross-sections of the house. }\end{array}$ \\
\hline $\begin{array}{l}\text { 8. } \\
\text { Fig. 8. The hills, Paštrovići } \\
\text { [M. Grbić]. }\end{array}$ & $\begin{array}{l}\text { - A row under the joint shelter } \\
\text { of single slope or double slope roof, } \\
\text { some of the single slope roofs are of } \\
\text { different height, different cross sec- } \\
\text { tions of the house. }\end{array}$ & $\begin{array}{l}\text { (111 } \\
\text { Fig. 12. Vrba, Paštrovići [M. Grbić ]. }\end{array}$ & $\begin{array}{l}\text { - There are several examples } \\
\text { where only two houses of the same } \\
\text { type are placed parallel one to an- } \\
\text { other [2]. }\end{array}$ \\
\hline $\begin{array}{l}\text { Fig. 9. Reževići, Paštrovići [M. Grbić]. } \\
\text { Fold }\end{array}$ & $\begin{array}{l}\text { - A row under the joint shelter of } \\
\text { double slope roof set longitudinally } \\
\text { in relation to the contour lines and } \\
\text { with the same cross-section of the } \\
\text { house. }\end{array}$ & $\begin{array}{l}\text { Fig. 13. Sveti Stefan, Paštrovići } \\
\text { [M. Grbić]. }\end{array}$ & $\begin{array}{l}\text { - Compact groupings of houses - } \\
\text { cluster structures, where the houses } \\
\text { are placed in both directions in rela- } \\
\text { tion to the contour lines - longitudi- } \\
\text { nally and transversely. }\end{array}$ \\
\hline $\begin{array}{l}\text { Fration } \\
\text { Fig. 10. Brce, Paštrovići [M. Grbić]. }\end{array}$ & $\begin{array}{l}\text { - A row without regular-group- } \\
\text { ings formed spontaneously accord- } \\
\text { ing to the terrain capability. }\end{array}$ & $\begin{array}{l}\text { Fig. 14. Sveti Stefan, Layout } \\
\text { [M. Grbić]. }\end{array}$ & \\
\hline
\end{tabular}

es even up to 2-3 kilometres, as a result of a very slope terrain. The land around the houses is rich in cultivated soil, cleared on the mountain slopes in the form of terraces and underpinned by dry stone walls. They are located in the background of the mountain slopes as well as in the lateral valleys (sloping towards the Bay of Tivat), formed on natural terraces (Fig. 4) [4].

\section{Villages of Mixed Type}

These settlements are a combination of the above mentioned types. Each of these villages is not only a geographical entity, but an economic and religious community as well. Each village has a district area, supplied with its water system, with one or two threshing floors. Villages of this type have been formed in Pastrovici area, as well as in the Bay of Kotor (Fig. 5) [2].

\section{Coastal Villages}

These settlements, that emerged beside the coast in the bay area of Kotor and Tivat, are of more recent date. The houses are built in a row only on one side of the coastal road, and it is difficult to determine the boundary between the villages, which gives them characteristics of a small town. The first rows of houses have been carefully processed. Coastal villages have become part of the settlements of scattered type (Fig. 6) [3].

In relation to the location, the following types of house groupings can be observed:

The detached houses are rare to be seen, that is why they are often included in the groups of houses, forming the rows of units and cluster structures. 


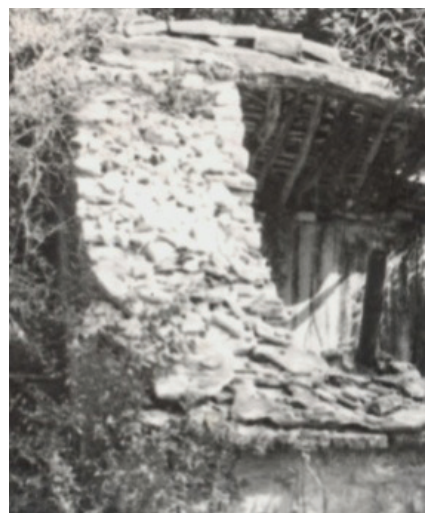

Fig. 15. Wall [M. Grbić ].

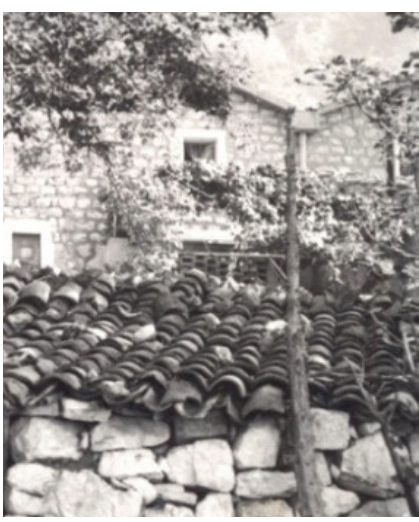

Fig. 16. Roof cover [M. Grbić ].

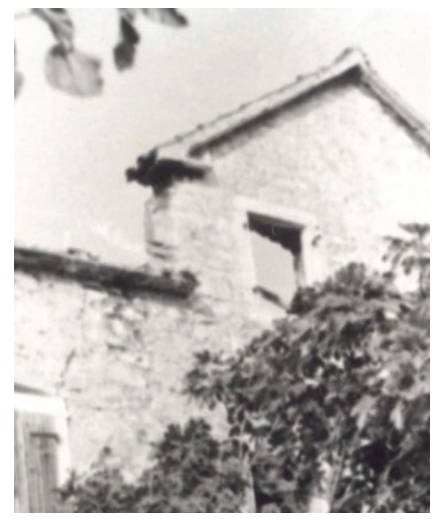

Fig. 17. Eaves [ M. Grbić ].

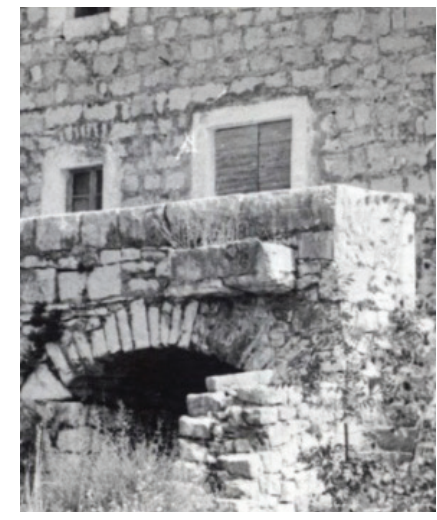

Fig. 18. Terrace [M. Grbić ].
The row of houses consists of 5-7 units, which can be seen even today. For seismic reasons, the number of houses in the row should not be exceeded.

The row always follows the configuration of the terrain and sometimes it is slightly curved. In order to achieve it, a number of houses must be of the same cross section and under a joint shelter of single slope or double slope roof, not including the same cross section of the base. Single slope roof is characteristic of the houses placed along the contour lines in Paštrovići area. However, the double slope roof, which is present as well, does not determine the same cross section of the house. The rows can be divided into the ground floor and first floor rows which are more often.

The first floor rows were built before the detached houses. According to the traditional organic development they represent the lower stage of the detached houses. The main characteristic feature of the front yard is that it is not divided - reconstructed. There are also rows set transversally to the slope (with joint ridge set vertically on contour lines).

The houses built close together in both directions along the contour lines - transversely and longitudinally or clustered in two or more parallel rows along the contour lines represent the compact groupings - cluster structures, which are less common than the traditional rows. Different types of groupings of houses are represented in the Table I.

\section{Constituent Elements of Houses}

\section{A. Yards}

The house was always in the backyard which usually is of the same width as the house. The shape of the yard is an elongated rectangular area of several dozen square metres and of economic character. The organization of the yard is rational and simple, fenced by stone walls and paved with stone slabs. All the buildings needed for the household are in the yard. Courtyards are not partitioned into units as houses are. Main entrance is through the front gate, reduced usually in the form of an arc or a stone framework. Grape vine spreads above the courtyard, creating a pleasant shade [6].

\section{B. Walls}

The walls were made of roughly piled or piled stone, constructed in lime or a lime mortar. They were constructed with two 50-80 cm thick faces. Both outer and inner side (both faces) of the wall were made of roughly piled stone, while their centre was filled with broken and smaller stone "riprap". Walls of houses were made of selected and carefully piled stone with roughly levelled horizontal connections (Fig. 15) [8]. Wall thickness of contemporary houses has decreased to $30-40 \mathrm{~cm}$, and so has the quality of buildings. Corner blocks were slightly larger and properly processed. The longitudinal walls of houses were finished with wreath made of stone slabs (kotali). Gable walls were also made of stone slabs measuring $10 \mathrm{~cm}$.

\section{Roof}

Present roofs are mostly single and double slope roofs, but they can also appear as triple or fourfold slope roofs. Single slope roof is characteristic of the houses placed along the contour lines and creates an obstacle for damaging the back wall of the house by rainwater flow or strong wind (bura). Double slope roofs are in the lee. The roof construction is always made of wood. Single slope roof inclination is very small, around $20^{\circ}$, double slope roof- around $30^{\circ}$.

\section{Roof Cover}

In older and single-storey houses, roof cover was made of stone slabs, $4-5 \mathrm{~cm}$ thick. Dominant roofing was half-round tile (hogsback tile) (Fig. 16). It was laid between the boards in two lines.

\section{E. Eaves}

The eaves of thin stone slabs were put $15-20 \mathrm{~cm}$ under the roof (console), forming a drip (Fig. 17). Gutters of Korcula stone were used to drain rainwater flows into the tanks.

\section{F. Mezzanine Structure}

It is completely wooden. Older mezzanine structures lean against stone walls or holes in the wall. Mezzanine structure 


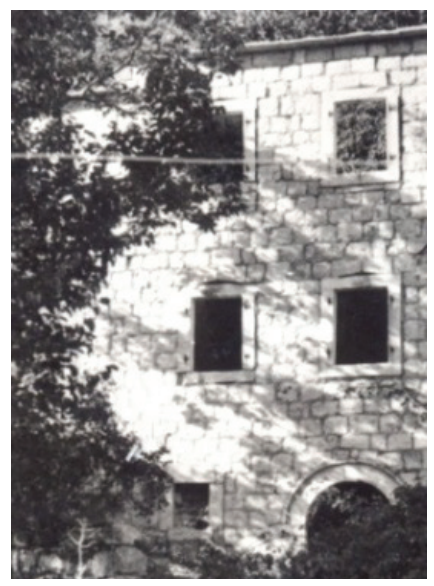

Fig. 19. Window frames [M. Grbić ].

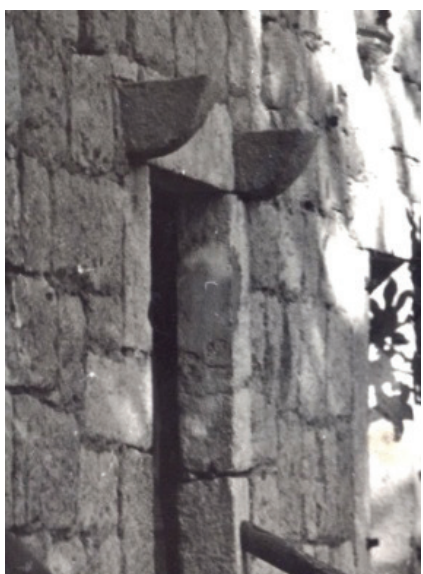

Fig. 20. Door frame [D. Tomanović].

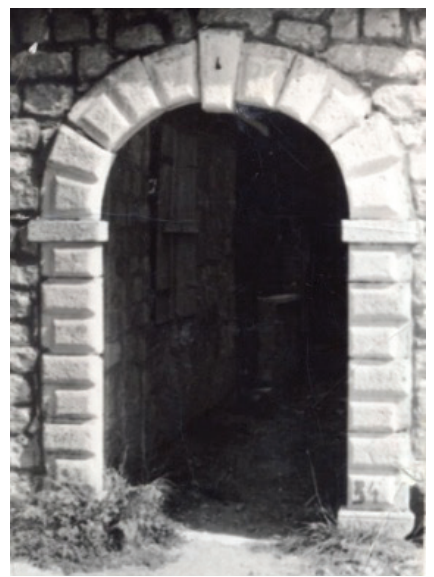

Fig. 21. Door frame [D. Tomanović].

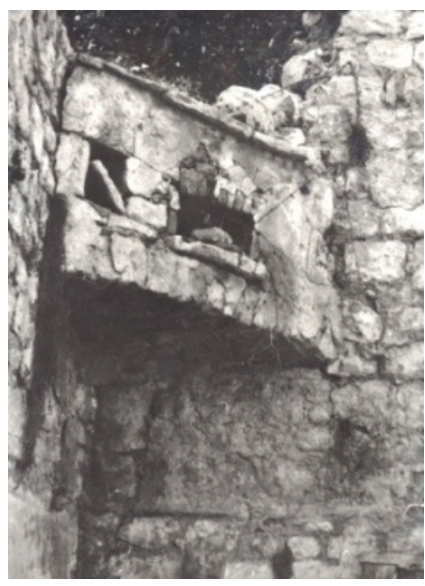

Fig. 22. Bread oven [M. Grbić ].
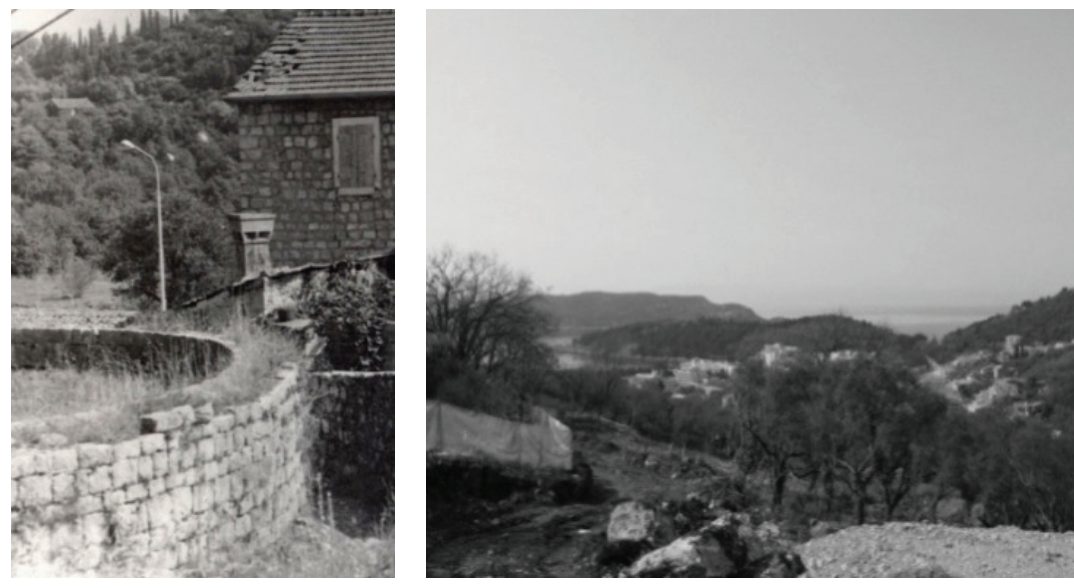

Fig. 24. Ivanovici location, Becici [M. Grbić ].

Fig. 23. Gumno [M. Grbić ].

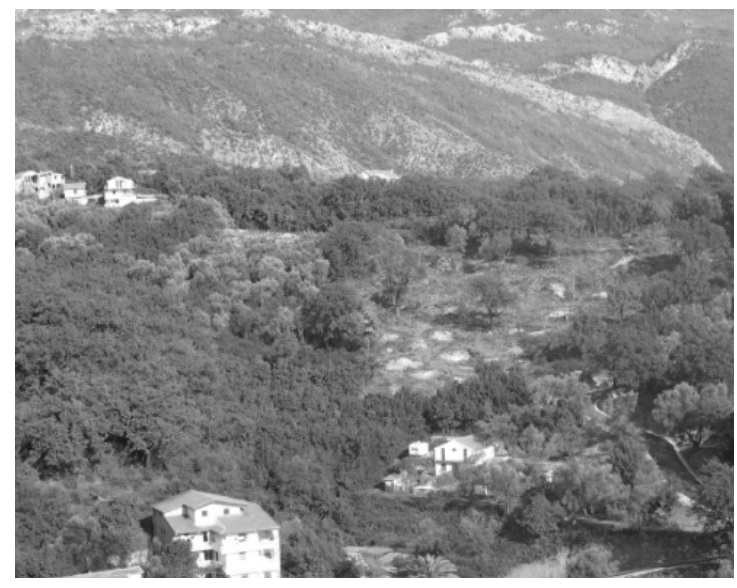

Fig. 25. Ivanovici location, Becici [M.Grbić ]. beams are laid on stone console beams in lines. The beams are supported by a thick wooden column. Mezzanine structure is covered with boards [5].

\section{G. Stairs}

They appear as external and internal. External stairs are made of roughly piled stone. They lead through the courtyard and balcony to the first floor. They have no railing.

\section{H. Terrace}

In the upper villages the terrace is common, while in the lower villages it is rare to be found (Fig. 18). When the terrace is on the level of the first floor it allows direct access to the residential rooms on the first floor. It is supported by an element of constructed arc "volat", which appears as the bearing structure of the terrace. Its width is modest, usually one-half the width of the house. Paved with dressed stone slabs of a rectangular shape, the terrace is enclosed by a bench with a seat and back made of steep stone slabs. Instead of terrace, modest houses have eaves made of wooden beams and grape vine "pergola" creating a pleasant shade.

\section{Windows}

Windows are of different dimensions and are located on the side facing the sea. They are equipped with full wooden shutters, usually painted green or blue. All openings are framed with stone thresholds (Fig. 19). Stone consoles, known as top consoles (auriculae), are of the height of the window, have a beam with round holes and serve as holders of the pole on which the curtain cloth is hitched. Bottom consoles (dentes) in the level of stone threshold serve as a place for the board for fruit.

\section{J. Doors}

Doors are either single or double, built from untreated wooden boards arranged horizontally with transversal stiffener plate. Doors, as well as windows, are framed by stone threshold from the island of Korcula (Fig. 20, 21). They are 80-100 cm wide and 


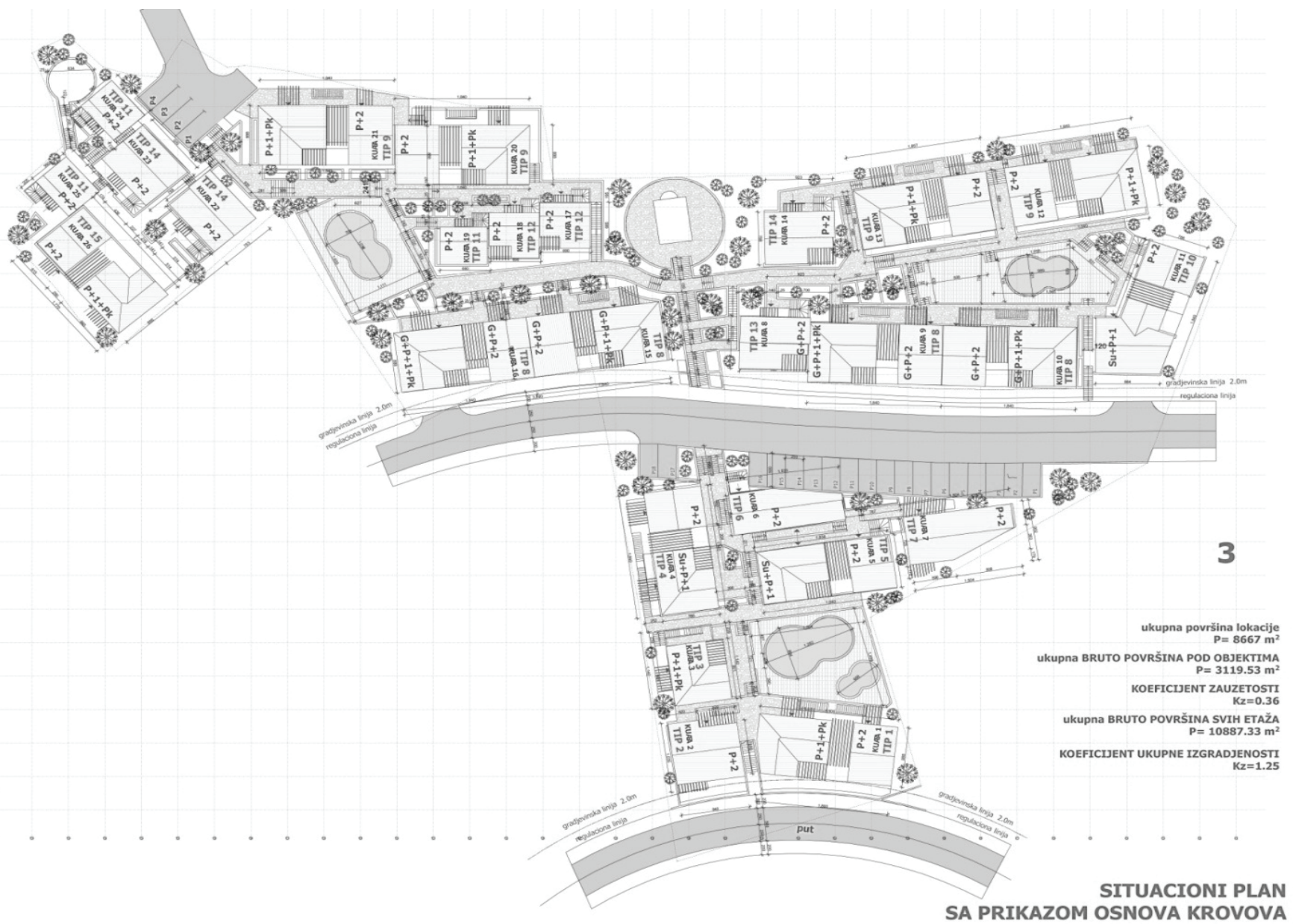

Fig. 26. Ivanovici settlement in Becici, Montenegro: Layout [ M. Grbić ].

170-180 $\mathrm{cm}$ high. In coastal areas the doors may be arched and made under the influence of a townhouse.

\section{K. Fireplace}

It is placed in the attic in order to enable ventilation. It is common to find two fireplaces in the same room - one in the middle or against the wall and the other (baking brick stove) in the corner (Fig. 22).

\section{Threshing Floor "Gumno"}

Threshing floor is a paved circular plateau surrounded by a stone wall with an opening-door. In the middle of the threshing floor there is a circular stone slab with an iron or wooden pole in the centre, to tie a horse during the threshing (Fig. 23).

\section{Furniture}

It is mostly of recent date. Dishes have changed more in material and processing than in their shape. The earliest pottery was made of terracotta and copper. The latest dishes are made of stainless steel. There is not much furniture: antique bed $1 \mathrm{~m}$ high, two or three closets, one or two chairs and few tripods, wooden benches, a table. The kitchen has generally retained some of the old equipment.

\section{N. Stonemasons}

The villagers built the houses themselves, though at that time freemasonry was quite developed, especially under the influence of Kotor and Bar. Stonecutters Dibrani, as well as stonemasons Gogo, immigrants from Albania, were common builders in this area.

The division into types was made according to eras in which the houses were built. Material has remained the same - the stone, which is abundant in this region. Openings on the houses were small, perhaps insufficient for normal lighting. The first floor was used for day and night dwelling. With the improvement of living conditions, new opportunities have emerged. Houses are under a strong influence of nearby cities (summer houses, villas, multi-storey houses). The influence of a Mediterranean house can only be assumed and compared with Hellenistic megaron, which was one of the basic models that influenced the architecture throughout Mediterranean. Its influence is evident in the house design, regular square spaces, double slope roof, binders, position 


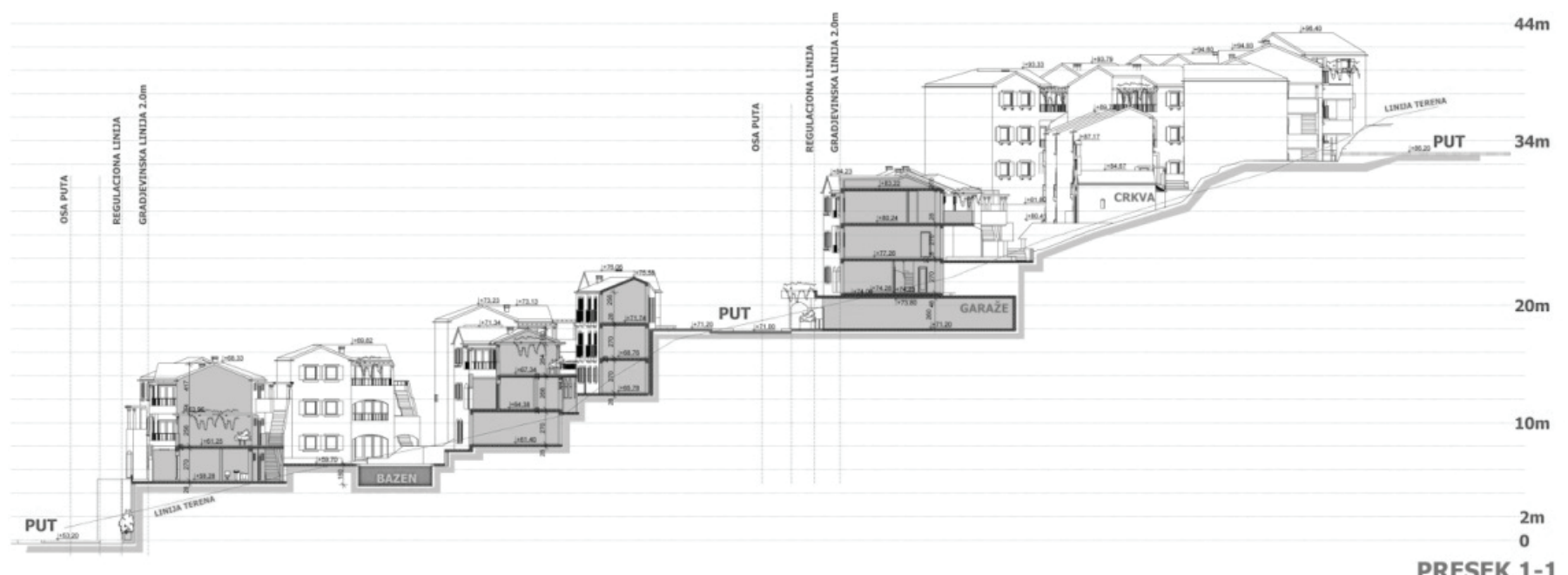

Fig. 27. Ivanovici settlement in Becici, Montenegro: Intersection [M. Grbić ]

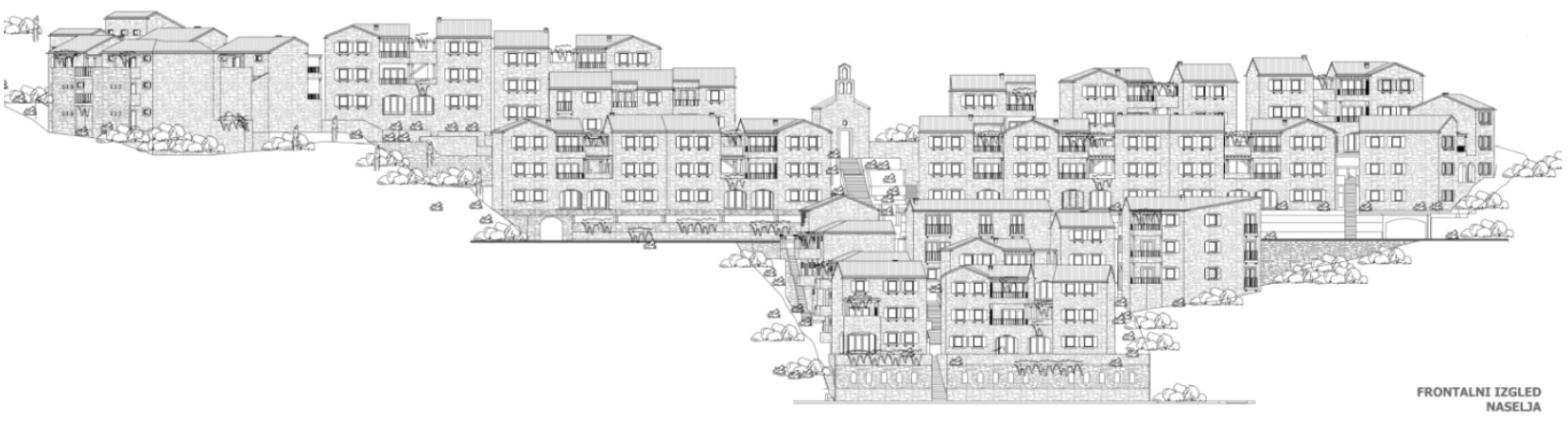

Fig. 28. Ivanovici settlement in Becici, Montenegro: Front View [ M. Grbić ].
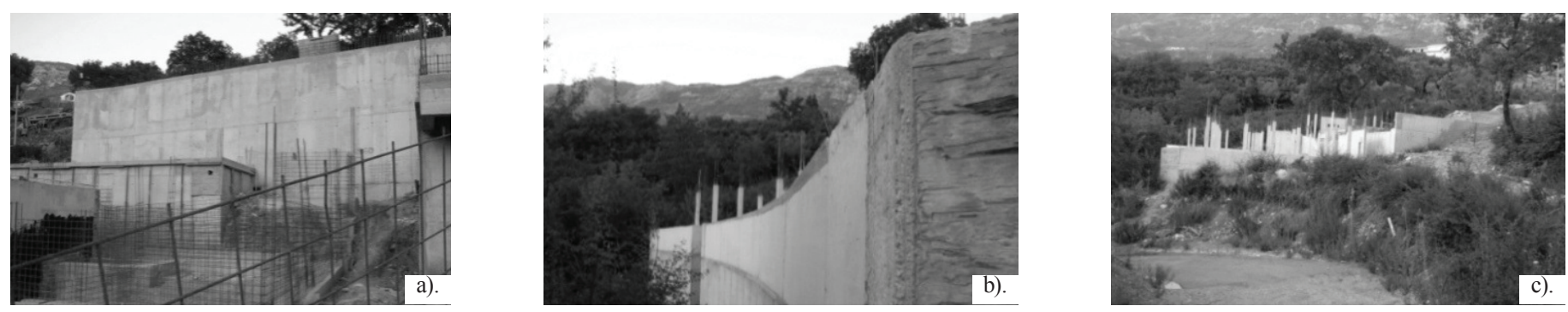

Fig. 29. a), b), c) Ivanovici settlement, beginning of the construction [ M. Grbić ].

relative to the ground. Under the influence of climatic conditions, single slope houses were built - characteristic of Paštrovići area, often with double slope roofs covered with hogs-back tile. Socio-economic, historical, climatic and geological factors as well as building traditions influenced the architecture of this area. The analysis of all these factors allowed to classify the houses as unique and special type of Adriatic coastal houses. As such, they represent an abundant source of research in order to create greater harmony between the old and the new [6].

\section{Case Study}

As a result of the review of the old buildings, observing all the qualitative and functional advantages of traditional buildings that have witnessed centuries of experience, and by respecting 

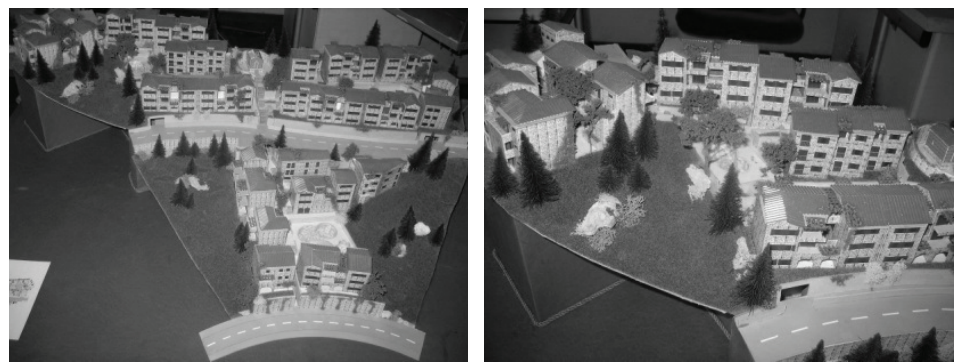

Fig. 30. Ivanovici Settlement, Model [ M. Grbić ].

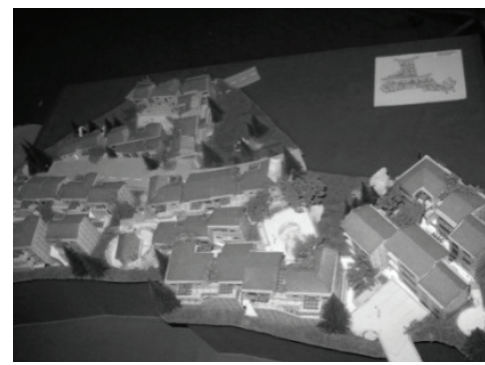

Fig. 31. Ornaments [M. Grbić].

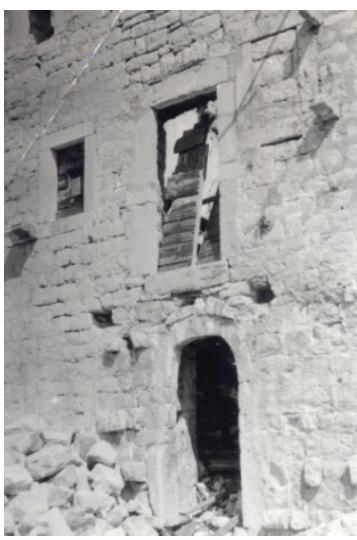

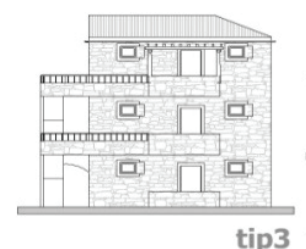

kua br.3

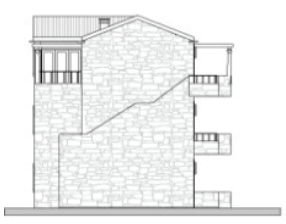

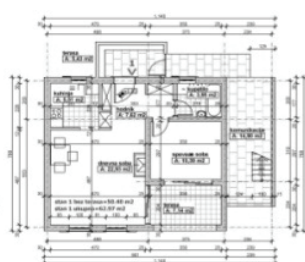

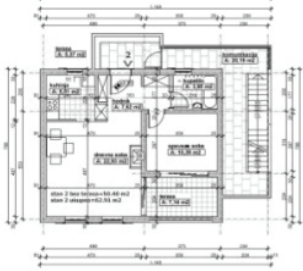

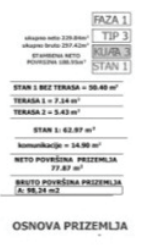

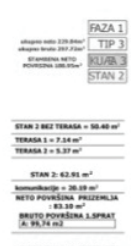

osNova 1.SPRAT
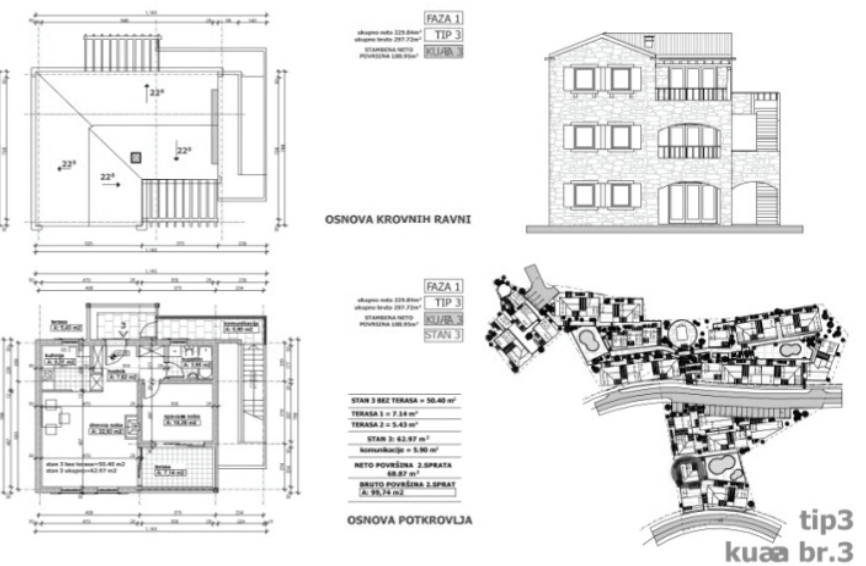

Fig.32. Ivanovici settlement in Becici, Layout Type 3 [ M. Grbić ].
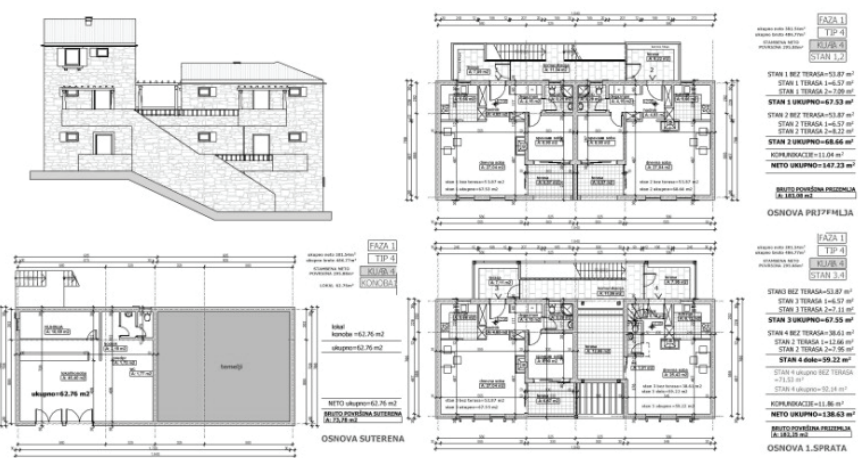

Fig. 33. Ivanovici settlement in Becici, Layout Type 4 [ M. Grbić ].

all local impacts of their sustainability, geographic location, the configuration of the terrain, climate and tradition - residential structures in cubic forms were designed, surrounded by authentic vegetation. Visual and stylistic compliance of the development with its surroundings was achieved to the largest extent.

Ivanovici settlement, located in the proximity to the seashore in Becici (Fig. 24), designed by architects Mirko and Dragan Grbic is a successful example of modern settlement designed based on the traditional ways of building, without losing regional characteristic features and identity (Fig. 25, 29 a, b, c).

The houses within the settlement are grouped like in the traditional settlements of mixed type (Fig. 26, 27, 28, 30). It consists of compacted and broken groups of houses with the most dominant type - ground floor, first floor and attic or ground floor and two stories (Fig. 32, 33, 34, 35). In this project basements are added according to the needs of modern living and urban settlements. There are underground garages. 

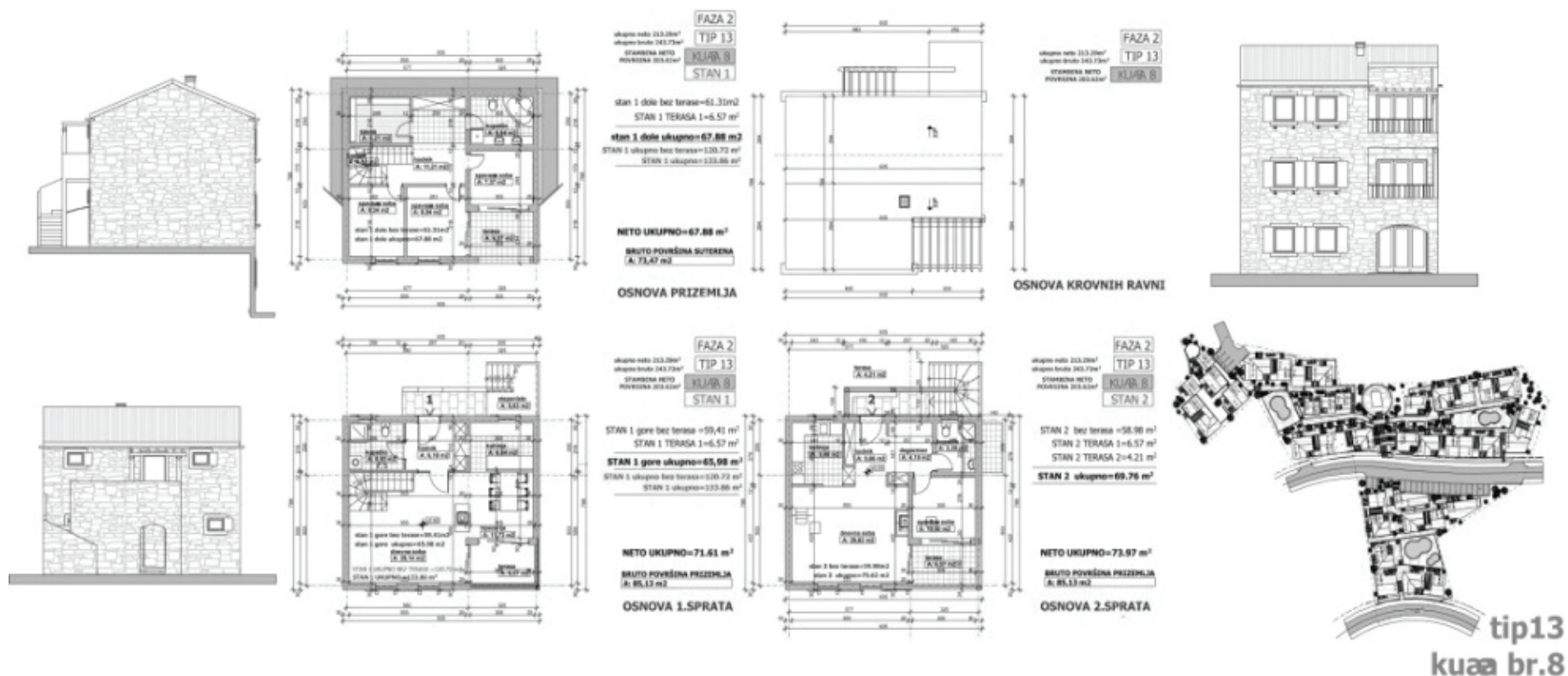

Fig. 34. Ivanovići settlement in Bečići, Layout Type 13 [M. Grbić ].
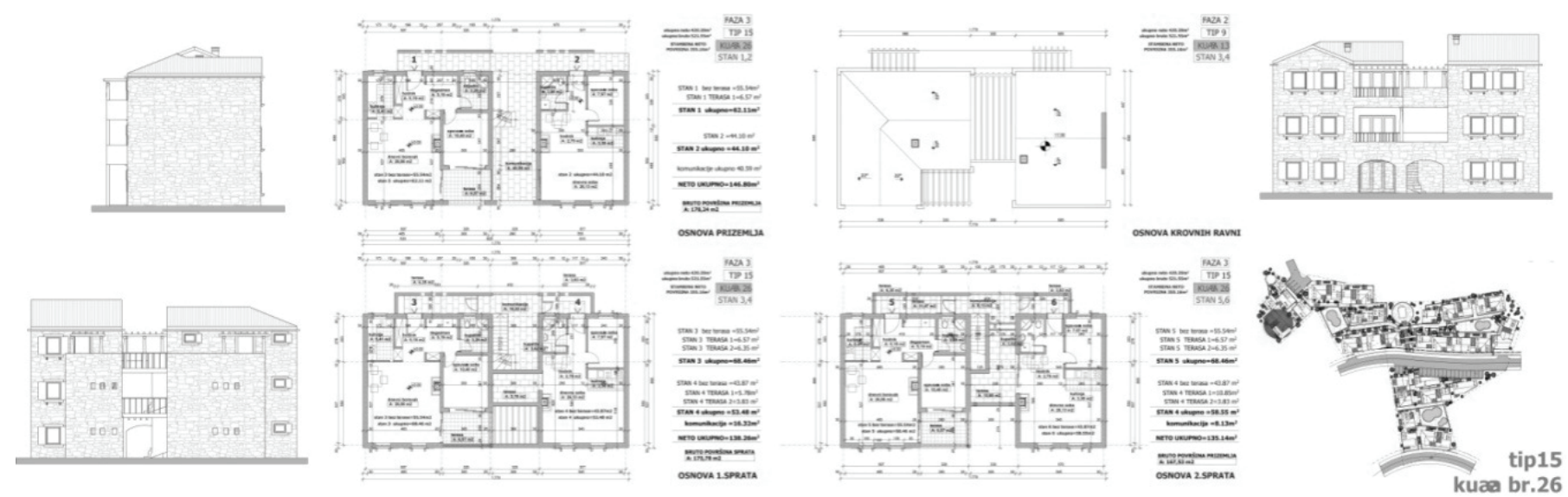

Fig. 35. Ivanovici settlement in Becici, Layout Type 15 [ M. Grbić ].
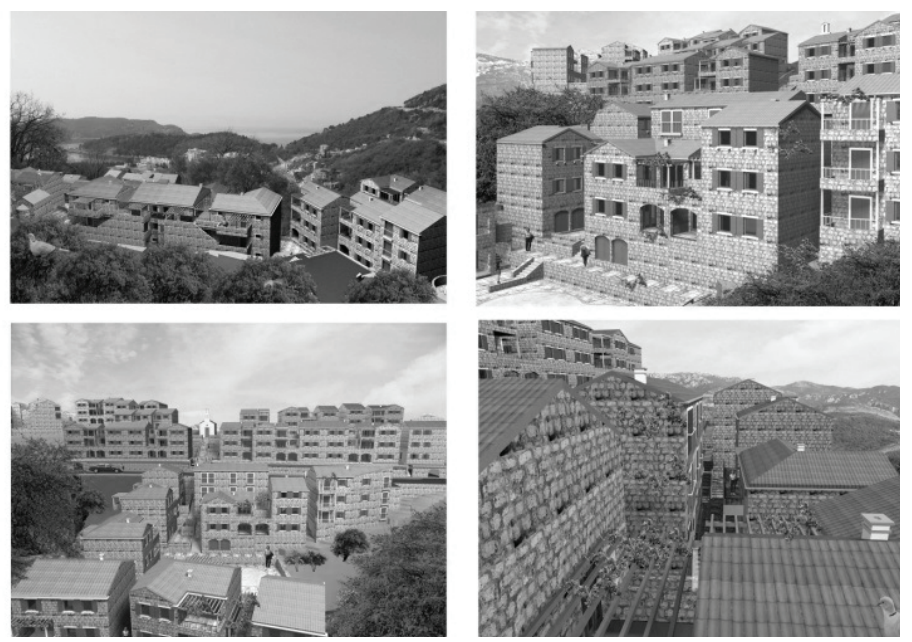

Fig. 36. Ivanovici 3D Model [ M. Grbić ].
This case study analyses how these relationships should be included in modern planning. When the environment is historically, artistically and culturally determined as valuable, as in this case, the new facilities should merge with their surroundings, often by copying certain elements adapted to modern technology and construction methods [7].

Thus, the basic structure is made of reinforced concrete, walls are multilayered, lined with stone, the ceiling and slope roof slabs are made of semi-prefabricated reinforced concrete, according to the seismicity of the area. When can it be said that a modern house is successfully designed?

When the visual compliance with its surroundings is achieved to the largest extent and when the design of facade, material and all the general attributes are accomplished. Size, proportions, materials, ornamentation around windows and doors (Fig. 31), edgings, as well as cornice under the roof should be fitted. 
All general attributes by Brolin have been accomplished withdrawal from the street, a distance of adjacent structures, mass relations, height, facade proportions, orientation, shape and silhouette, arrangement of windows and doors, size and proportions of windows and doors, materials, colours (Fig. 36). Historical and non-historical stylistic attributes have been observed as well (categories related to traditional and modern ornamentation and stylistic objects integrate into surroundings).

\section{Conclusion}

Contemporary urban planning in the Montenegrin coast failed to create anything new and better than what people have created for centuries according to their needs. Along the seacoast new settlements have been developed which are completely different from the old ones. They have endangered old settlements, both qualitatively and quantitatively, almost to their destruction.

The research draws attention to the essential elements that should be considered in determining the content of the contemporary program of modern housing units in the development policy.

The new development Ivanovici, located in the proximity of the seashore in Becici, is a successful example of a modern settlement designed by architects taking into consideration the traditional ways of building, without losing regional characteristics and identity.

The case study presented in this article describes the possibility of solving the contemporary design problem in a way which respects previously established local tendencies in urban design that have existed for many centuries.

\section{REFERENCES}

1. Kojić, B. Seoska arhitektura u Boki Kotorskoj. Spomenik SAN CIII, 1953, p. $165-175$.

2. Kojić, B. Seoska arhitektura u Paštrovićima. Belgrade: Glasnik etnografskog institute, knjiga IV-VI, 1957, p. 64-87.

3. Božović, G. Naselja i kuće Tivatskog zaliva. Centar za planiranje urbanog razvoja, 1980, p. 25-75.

4. Božović, G. Urbanistički projekat oživljavanja seoskih naselja Tivatskog zaliva. Centar za planiranje urbanog razvoja, 1986, p. 15-24.

5. Đurović, V. O konstrukciji kuća od XVI do konca XIX veka u Kotorskom zalivu i njihovim graditeljima. Spomenik SAN CIII, 1953, p. 147-164.

6. Petrović, Z. Selo i seoska kuća u Boki Kotorskoj. Belgrade: Zbornik Arhitektonskog fakulteta, knjiga III sveska 9, 1956/1957, p. 5-10.

7. Brolin, B. Arhitektura u kontekst. Belgrade: Građevinska knjiga, 1985, p. 279-295.

8. Tomanović, D. O konstrukciji kuće porodice Tomanović iz 1826. godine u Lepetanima - Boka Kotorska. Izgradnja, No. 66, 2012, p. 7-8, p. 395-399.

9. Map of the Montenegrin coast [online]. Google Maps [cited 01.09.2014]. https://www.google.com/maps/place/

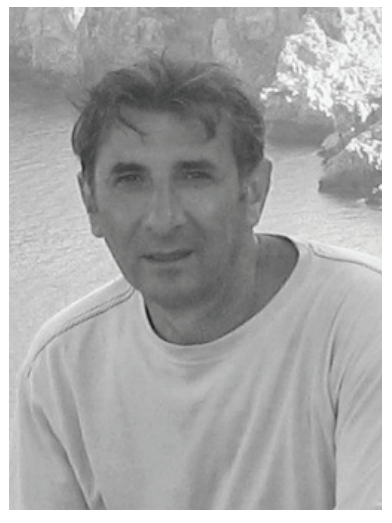

Mirko Grbić received the Master's degree in Architecture and Urbanism from the faculty of Architecture, University of Belgrade in 1993 and Doctor's degree from the Faculty of Architectural Management of University "Union-Nikola Tesla" in 2012.

From 1985-2013, he was an Assistant with the Department of Architectural Design and Urban Planning of faculty of Architecture, University of Priština. He is the author and co-author of major architectural projects in various fields, most of which are residential settlement projects, residential multi-story buildings, multi-story villas, family houses, tourist facilities, public facilities projects. He has participated in international scientific conferences.

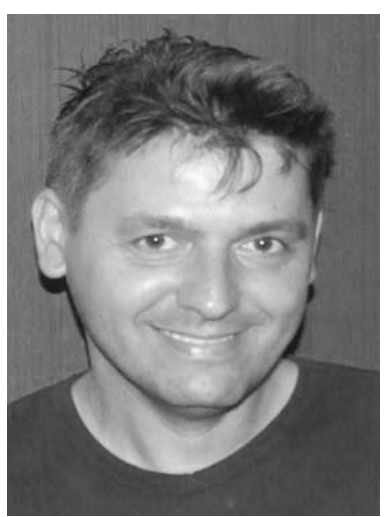

Dušan Tomanović graduated from the Faculty of Architecture in Priština in 1995. He received the Master's degree in Architecture and Urbanism from the faculty of Architecture, University of Belgrade in 2004 and Doctor's degree from the faculty of $\mathrm{Ar}$ chitecture, University of Belgrade in 2014. From 1996, he was an Assistant with the Department of Architectural Design and Urban Planning of faculty of Architecture, University of Priština. From 1999-2000, he was involved in the projects of the Institute of Transportation CIP in Belgrade.

$\mathrm{He}$ is the author and co-author of major architectural projects in various fields, most of which are residential multi-story villas, family houses, tourist facilities and several urban plans. He is the author of several scientific publications (in Serbian and English), and has participated in different research projects and studies.

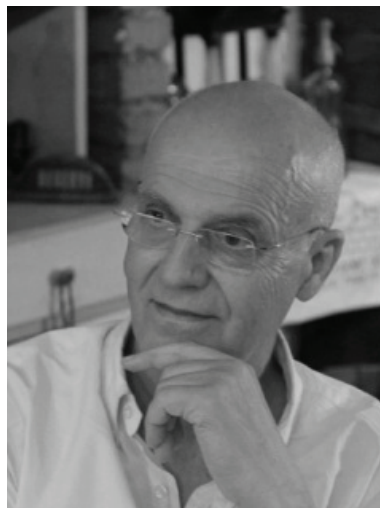

Peter Gabrijelčič received M. Sci. from the Faculty of Engineering, Geodesy and Architecture of University of Ljubljana in 1985. He is a Professor at the Faculty of Architecture of University of Ljubljana (UL FA). He lectures in architectural design, urban design, landscape architecture and tutors design studio work. He is the Dean of the Faculty of Urban Planning and Architecture of the University of Ljubljana. He has received many awards such as the Borba Award for Slovenian Architecture, Prešern Foundation Award, Belgrade Salon of Architecture Award, Architecture Event of the Year Award in Belgrade, European Architectural Award in London, Trend Award. He is also a winner of the Golden Pencil and the Platinum Pencil awards of the Slovenian Chamber for Architecture and Space. He has been a co-author of a number of projects for international competitions. He has carried out significant bridge structures in Slovenia and abroad.

His research areas are as follows: spatial and urban planning, urban regeneration, models for revitalisation of degraded urban areas, analysis of trends of spatial development, ruralism and rural architecture, bridge construction. Since 1990, he has been a visiting lecturer in different countries. He has participated in EU projects/Programmes. 


\section{Contact Data}

\section{Mirko Grbić}

University of Priština in Kosovska Mitrovica

Fakultet Tehničkih nauka

Address: 7 Kneza Miloša St., 38220, Kosovska Mitrovica

E-mail:mirko.grbic@pr.ac.rs

\section{Dušan Tomanović}

University of Priština in Kosovska Mitrovica

Fakultet Tehničkih nauka

Address: 7 Kneza Miloša St., 38220, Kosovska Mitrovica

E-mail: dusan.tomanovic@pr.ac.rs

\section{Peter Gabrijelčič}

University of Ljubljana, Faculty of Architecture

Address: 12 Zoisova St., 1000, Ljubljana, Slovenia

E-mail: peter.gabrijelcic@fa.uni-lj.s1 